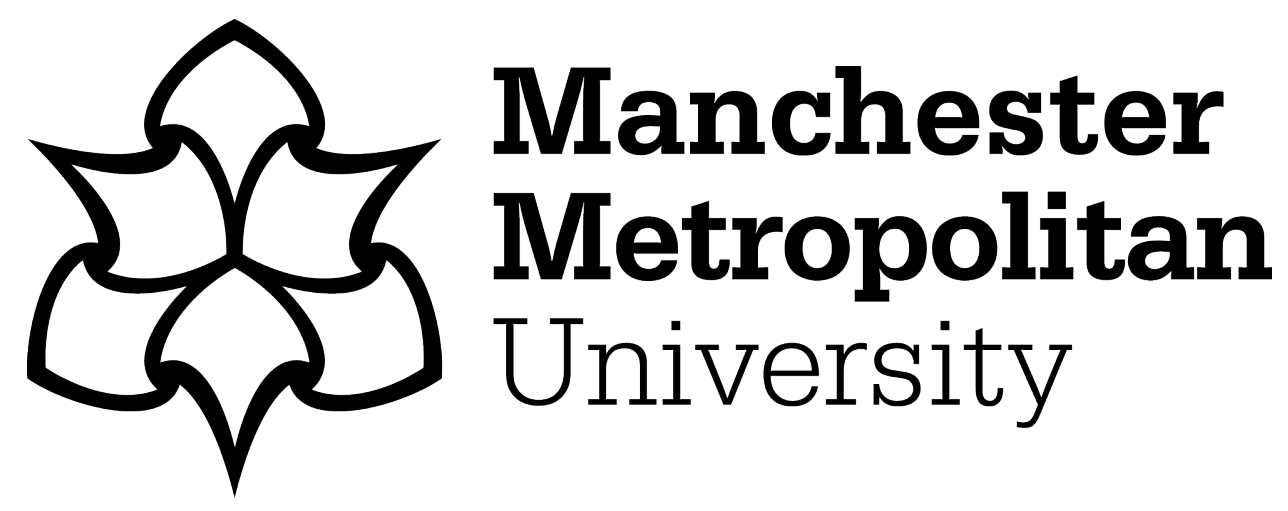

Buzdugan, S ORCID logoORCID: https://orcid.org/0000-0002-9679-1649 and Tuselmann, H (2018) Making the Most of FDI for Development:'New' Industrial Policy and FDI Deepening for Industrial Upgrading. Transnational Corporations, 25 (1). pp. 1-21. ISSN 1014-9562

Downloaded from: https://e-space.mmu.ac.uk/620266/ Version: Accepted Version

Publisher: United Nations Conference on Trade and Development

Please cite the published version 


\title{
Making the most of FDI for Development: "New" industrial policy and FDI deepening for industrial upgrading ${ }^{1}$
}

\author{
Stephen R. Buzdugan \\ Centre for International Business and Innovation, Manchester Metropolitan University Business \\ School, Manchester, UK \\ Heinz Tüselmann \\ Centre for International Business and Innovation, Manchester Metropolitan University Business \\ School, Manchester, UK
}

\begin{abstract}
This article examines the theoretical and empirical links between a new generation of industrial policy, which is rapidly emerging as a dominant paradigm in development economics, and foreign direct investment. It finds that thus far, the theoretical role of FDI in "new" industrial policy has been vague, despite openness to FDI being one of the characteristics which sets it apart from an

'old' generation of industrial policy which advocated protectionism. Based on primary and secondary research, the article argues that a set of interventions into the economies of low and lower-middle income countries combined with an in-depth understanding of the complex interactions involved in TNC subsidiary upgrading, the internationalisation processes within TNCs and TNC strategies and objectives on the part of policy makers, offers such countries the opportunity to maximise the benefits of FDI and move further up in global value chains.
\end{abstract}

Keywords: FDI upgrading, subsidiary development, industrial policy, economic development

\section{Introduction}

After several decades as a controversial sideshow, industrial policy is taking the centre stage again in mainstream development policy thinking (Stiglitz et al., 2013; Wade, 2012; Lin and Chang, 2009; Hausmann et al., 2008). This shift is a response to the growing recognition that the liberalization of trade and investment, which have been pursued in developing countries since the 1980s, has alone been insufficient in promoting economic growth (Harrison and Rodríguez-Clare, 2010). Industrial policy, however, has taken on a more contemporary form, breaking with its past association with hardline protectionism and advocating instead "softer" forms of interventions by governments to promote production upgrading and diversification (Wade, 2012: 236; Harrison and Rodríguez-Clare, 2010). For low and lower-middle-income economies especially, the focus of debates and practice has been on the role of industrial policy to promote exports and become incorporated into higher levels of global value chains (GVCs) (Haque, 2007; Gereffi, 2014: 442; Pérez, 2014). In this regard, the role of trade policy has understandably been seen as essential and thus, debates have focussed on whether governments should "conform" to or "defy" their respective

\footnotetext{
1 This article is informed by a previous Research Note by the authors for the 2016 UNCTAD Expert Meeting on Taking Stock of International Investment Agreement Reform (Tüselmann and Buzdugan, 2016).
} 
countries' comparative advantage (Lin and Chang, 2009) and then what policies may be effective in doing so under World Trade Organization (WTO) rules, which limit the range of intervention by governments (Gereffi, 2014: 438; Wade, 2012: 237; Harrison and Rodríguez-Clare, 2010: 41134114). While the role of "soft" forms of industrial policy with respect to foreign direct investment (FDI) has also been recognized as key to encouraging growth through upgrading activities, the treatment of how such upgrading can occur through FDI has been somewhat "broad brush" in the development literature, referring generally to FDI promotion and its potential positive spillover effects (see for instance Lin, 2012a and Lin, 2010).

This article seeks to address this gap by shedding light on how FDI can be an important component in a "new" generation of industrial policies to further economic development in lower income countries. Specifically, it argues that to avoid being trapped in the low end of the value chain by the entrenchment of low-value-added activities associated with FDI, low and lower-middle-income developing countries should tailor their efforts to attract higher-value-added FDI and upgrade existing FDI towards more higher-value-added operations through a "new" set of industrial policies. $^{2}$ Put differently, it argues that the attraction of a significant volume of FDI, which is implied in much of the existing literature on FDI and industrial policy, is a necessary but insufficient condition for FDI to contribute to development objectives, and that what matters instead is industrial policy to improve the quality of attracted and existing FDI. In this respect, it agrees with Gereffi (2014: 455) that the wholesale attraction of multinational corporations (TNCs) per se by developing country governments may present a risk toward domestic production upgrading, particularly in low and lower-middle-income countries:

If low-value-added activities dominate a specific country or region, then consequences [of FDI] for economic performance and social welfare can be profound. Specifically, entrenchment in narrow, routine, low-value-added activities can lock firms and national industries into unprofitable and intellectually narrow segments of the value chain. Learning might be rapid at first, but over time such limits can become acute, especially if lead firms in GVCs move to new sites for low-cost production and more promising markets.

Based on evidence from both developed and developing countries, this article posits that such a "new" generation of industrial policies should occupy some "middle ground" within the current debates, be broad sector based (rather than aimed at particular industries) and focus on "activities" in a cross-cutting way, especially those that are new to the economy and that maybe transferable across sectors (for instance, such a notion is implicit in a number of recent research and policy

\footnotetext{
${ }^{2}$ See for instance UNCTAD (2013) for an overview of the importance of moving to the higher end of global value chains for developing countries.
} 
papers on the development of agribusiness value chains (Heumesser and Schmid, 2012; SchaffnitChatterjee, 2014)). The purpose of such policies is to, on the one hand, contribute to a certain level of local capabilities and absorptive capacity necessary to upgrade FDI towards HVAs and channel FDI into key areas of productive capacity building. Yet on the other hand, the potential for FDI upgrading relates to policies which are informed by an understanding of the complex interactions involved in TNC subsidiary upgrading, the internationalisation processes within TNCs and TNC strategies and objectives, in order to generate "win-win" situations for both investors and host countries, as we provide evidence for.

In this regard, the article suggests that success in formulating these policies will be based on increasing the understanding amongst policymakers of the internationalization processes, objectives and overall strategies of the investing TNCs - including the complexities associated with potential impacts on domestic productivity and skills, among other effects - in order to maximize the quality of inward FDI and promote FDI upgrading. This is a crucial point: as many approaches aimed at developing FDI towards more HVA operations are resource intensive, policymakers in low-income countries (with large funding gaps to build and sustain requisite productive capacity bases) seeking to promote $\mathrm{TNC}$-assisted industrial upgrading strategies require policies based on evidence of the complexities in FDI upgrading. One example of such complexities is how the dual embeddedness of TNC operations (i.e. embeddedness within the host country and within the wider TNC organization) influences subsidiary development and upgrading (Andersson et al., 2005; Birkenshaw et al., 2005; Ghoshal and Bartlett, 2005; Meyer et al., 2011), which has thus far been rarely accounted for in influential FDI impact studies and policy prescriptions. ${ }^{3}$ Thus, this article supports such evidence-based policymaking by presenting the results of extensive original research by the authors performed in a "developed" country context (supplemented by evidence from "developing" country contexts) which show that such FDI upgrading is relatively rare but possible if a number of "lessons learned" in such contexts are applied.

This article proceeds as follows. First, we discuss the contemporary debate on industrial policy and seek to explain how "middle ground" within this debate may be found. Then, we present an argument based on insights from the international business (IB) literature and the results of largescale representative micro level survey-based studies in the United Kingdom, Germany and Scandinavia that it is the quality of FDI is what matters for production upgrading and growth, rather than the attraction of FDI per se. From this, we examine the emerging evidence in the economic

\footnotetext{
${ }^{3}$ For instance, see two recent World Bank studies - Farole and Winkler (2014) and Echandi et al. (2015) - for a comprehensive review of the empirical literature.
} 
development literature on the ways "new" forms of industrial policy have been used in "developing" countries in order to maximize the developmental effects of FDI. Finally, based on these two sets of evidence, from "developed" and "developing" countries, we conclude by suggesting a set of policy areas and policy considerations that have been shown to attract highervalue-added FDI and upgrade existing FDI towards more higher-value-added operations.

\section{The contemporary shift toward a "new" industrial policy}

The term "industrial policy" has historically elicited two different forms of responses amongst those concerned with economic growth and development: some have praised it as the means by which a number of East Asian economies achieved rapid levels of economic development, while others have condemned it, citing failures of import substituting industrialization policies in parts of sub-Saharan Africa and Latin America in the 1960s and 1970s. Arguably, the reason for such opposing views, as Weiss (2011: 1) points out, "stems from the fact that here the structuralist and neoclassical traditions of development studies meet head-on, with the former seeing industrial policy as a means of correcting for the limitations of markets and the latter seeing it as the highpoint of "government failure".

Recently, there has been renewed interest in industrial policy within the mainstream strands of the field of economic development, which has accepted the pervasiveness of market failures in "developing" countries but has tried to design an approach to limit the potential for "government failure" (Hausmann et al., 2008; Lin and Chang, 2009; Stiglitz et al., 2013). Whilst there has been some consensus on the necessity of some form of industrial policy for economic development, the approaches that have been proposed thus far differ in the degree to which state intervention attempts to promote industrialization.

On one side of the contemporary industrial policy debate lay proponents, such as former chief economist of the World Bank Justin Lin, of the view that economic development is firmly rooted in a country's endowment structure and a private sector which responds adequately to prices reflecting the relative abundance and scarcity of its factor endowments. Governments, in this view, can actively promote the process of economic development by coordinating and facilitating the entry of firms into industries compatible with the country's latent comparative advantages and absorb the large externalities involved in industrial upgrading and improvements in infrastructure (Lin, 2012b: 406). As Lin (Lin and Chang, 2009: 486) has put it: 
the optimal industrial structure [of poor countries] is endogenous to the country's endowment structure - in terms of its relative abundance of labour and skills, capital, and natural resources. Upgrading the industrial structure requires first upgrading the endowment structure, or else the resulting industrial structure will become a drag on development. Therefore the government's role is to make sure that the economy is well launched on this endogenous process of upgrading.

Whilst there is an apparent logic to this approach, it fundamentally assumes that there is or will be a private sector that is mature enough to respond to and take full advantage of the "facilitating" and "coordinating" activities of the state. Furthermore, as Chang (Lin and Chang, 2009: 490-91) has rebutted, Lin's approach assumes that the factors of production are easily in place to specialize in the country's comparative advantage. As he points out, many poor countries exhibit limited factor mobility and limited access to technology, which may hamper their efforts towards industrial upgrading.

Ha Joon Chang, who supports the other side of the industrial policy debate, suggests that government should play a more active role to overcome the many complex barriers to industrial upgrading that poor countries are likely to face, which a "coordination" role may not be able to grapple with:

the industrial upgrading process will be messy. It will not be possible for a country to follow market signals closely and enter an industry when its factor endowments are right, as will happen with the smooth comparative-advantage-conforming strategy that Justin advocates. In the real world, firms with uncertain prospects need to be created, protected, subsidised, and nurtured, possibly for decades, if industrial upgrading is to be achieved (2009: 501).

Whilst these two approaches may appear divergent, they share quite a bit of common ground, mainly on the central importance of industrial upgrading for economic development and that the government should play a significant role in this process. Therefore, given that there is consensus on these core principles, a middle path can found. A number of works have emerged over the past decade that have sought to elaborate such a middle path. One key insight from this literature is that government intervention should be focussed on "activities" (a new technology, a particular kind of training, a new good or service), rather than on sectors per se - "it is activities that are new to the economy that need support, not those that are already established" (Rodrik, 2004: 14). Therefore, whether it is appropriate, given the country's set of resources, to stay close or attempt move slightly farther from its comparative advantages, the government needs to be able to promote and support new ways of producing. In relation to this, policies, institutions and activities need to be put in place to promote "learning" in the economy. Finally, Weiss (2011) suggests that elements from both sides of the industrial policy debate can be combined at different - that is micro and macro - 
levels, based on the work of Hausmann et al. (2008). At the "micro" level, governments, for example, can engage in dialogue with local industries to determine constraints to industrial upgrading, and seek to alleviate them through the establishment, for instance of public-private "deliberation councils" to identify roadblocks to upgrading and develop solutions to overcome them; and create centralised budgets from which public institutions can draw on state resources to alleviate such private sector constraints (such as training individuals in a necessary activity or improving a specific piece of infrastructure) (Hausmann et al., 2008: 5-10). At the macro level, governments can promote upgrading through, for instance, making credit available for "risk taking" ventures as well as choose to focus on a priority sector (not specific industry) of the economy to promote. However, these promotion activities need to be time-limited with clear performance criteria and transparency, to enhance the efficiency of those sectors receiving support.

Irrespective of the forms of intervention deemed necessary, one distinguishing characteristic of "new" industrial policy - and the one we draw most attention to in this article - is its open orientation towards foreign investment in order to harness its potential to build capacity, promote HVAs in the economy, and therefore participate in and capture the gains of higher levels of GVCs. This is a fundamental departure from "old" forms of industrial policy which had limited success in achieving such outcomes by closing off economies from foreign trade and investment, substituting them instead with often scarce levels of domestic demand and investment. Thus, the key to positive developmental effects of "new" industrial policy is its successful integration with existing and potential FDI. Yet, as we show below, such successful integration is by no means automatic or solely dependent on levels - i.e. of stocks and flows - of FDI, but depends on the quality of FDI and the ability of countries and their investors to promote upgrading.

\section{Deepening FDI for production upgrading}

FDI can play a role in sustainable economic development, poverty reduction and industrial upgrading in lower income countries (Kolk et al, 2017). However, the attraction of a high volume of FDI is not a sufficient condition for FDI to contribute to these objectives. What matters is the quality of FDI, in terms of higher value added FDI and the development of existing FDI towards more higher value activities with associated positive spill-over effects to the domestic economy. Direct and indirect benefits associated with upgrading of FDI include (but are not limited to) higher productivity, more skilled employment and technological advancement. Such "upgrading" of FDI is at that heart of Narula's and Dunnings's (2010) "MNC assisted development strategy". Since developing countries exhibit different degrees of economic development, possess different endowments and locational asset bases, different static and dynamic comparative advantages, 
varying degrees of market and/or co-ordination failures and have different development objectives and strategies, a fundamental issue is whether upgrading of FDI, or FDI in general, are efficient paths toward economic development and industrial upgrading.

FDI upgrading is connected to an increasing emphasis on developing unique locational asset bases, efficient local network infrastructures (consisting of suppliers, customers, competitors, clusters of domestic firms, research institutes/universities, supportive government agencies/local authorities) and effective institutional frameworks that are attractive and desirable to TNCs to upgrade their activities and enable their subsidiaries to perform more HVA. Many of these assets are spatially bound. Therefore, the development of more HVA by foreign firms in their host locations is associated with them being deeply embedded in the host region and within efficient local networks and linkages to effectively access and leverage the tangible and intangible locational assets, which underlie the development of high productivity/high skills/high employment HVA. At the same time, the increasing emphasis of policymakers on the "new" embeddedness factors for upgrading and deepening FDI is connected with TNCs increasingly developing global value chains (GVCs) and seeking to develop their subsidiaries into a differentiated network, where some subsidiaries are more central to core aspects of overall TNC performance than others (which embodies a more footloose type of FDI) (Bartels et al. 2009; Birkenshaw et al, 2005; Rugman et al,2011). In this way, TNCs increase specialization within the TNC network and establish a differentiated network of subsidiaries in order to maximise competitive advantage through the development of their unique contributions, in order to fulfil the strategic objectives of the parent company. This suggests that subsidiaries which are more central to overall TNC performance and that can build up valuable assets which are not accessed by other parts of the TNC (or do so at higher costs), should be given mandates and strategic autonomy to deeply embed themselves in the host economy; to develop main business lines for international markets; or to perform specialist functions for all or part of the TNC.

If the upgrading of FDI is part of the wider development and industrial upgrading strategy, it has to be borne in mind that any direct and/or spill-over benefits are neither automatic nor cost- or riskfree. Crucially, these require a level of host country productive capacity in terms of local capabilities and absorptive capacity, and related investments to foster these, as well as international connectivity (UNCTAD, 2012).

With regard to expected FDI spill-over effects, much of the evidence points mainly to vertical spillovers (spill-overs to firms in linked industries: upstream and/or downstream sectors) rather than 
horizontal spillovers (spillovers to firms within the industry) (see Harrison and Rodriguez-Claire (2009) for a comprehensive overview). Low-income countries have generally weak absorptive capacity and local capabilities compared to high and middle high-income countries, as well as limited resources to invest in these (UNCTAD 2014a). For example, sub-Saharan African countries have generally placed greater emphasis on solely attracting FDI, as they have generally lacked the requisite infrastructure, skills and capabilities of domestic firms to capture the development potential of the employment, technology and productivity spill-overs associated with deeper embeddedness of TNC subsidiaries and related higher value added activities (Chen et al. 2015: 3536).

The more important need for policy-makers in low income countries then is for evidence-based policies based on an understanding of the complexities involved in FDI upgrading and subsidiary development towards more HVA, including the objectives and overall strategies of the investing TNCs, and the complex links to outcomes such as productivity, skills, and so forth. In light of the discussion above, this requires a framework of analysis that draws on insights from the IB strategy literature, including resource based and network theories of the firm, development economics and economic geography (e.g. Andersson et al. 2005; Birkenshaw et al., 2005; Cantwell and Mudambi, 2011; Coe and Perry, 2004; Dunning, 2009; Henderson et al., 2002; Goshal and Bartlett, 2005; Peng et al., 2009; Holm et al., 2000; Porter and Sövell, 1998), FDI upgrading and associated benefits depend on the combination and interaction of a number of factors at different levels.

Some of these factors are not new and are well versed, such as (i) a host country's endowments and its static and dynamic comparative advantages; (ii) The host location's possession of tangible and intangible location asset bases at national and sub-national level that are attractive for TNCs to pursue higher value added activities, including next to market and cost factors, spatially bound created assets; (iii) the host country's capabilities and absorptive capacities to attract, sustain and develop higher value added FDI activities; (iv) A host country's institutional, regulatory, policy and governance frameworks and in particular stable and business friendly investment climate next to political, economic and social stability. There has also been a growing appreciation in the economic development literature of the differential implications for the developmental potential of FDI depending on type of investment (e.g. greenfield, joint ventures and acquisitions) and FDI motives (e.g. market, resource, efficiency or strategic asset seeking) (Farole and Winkler, 2014; Zhan, Mirza and Speller, 2015). This is also the case of the importance of the degree of embeddedness of subsidiaries in the host country, in terms of local network relationships (inter- 
organizational relationships), to effectively access and leverage host country locational advantages and assets.

What is somewhat missing in the economic development literature and related studies, are insights from the IB literatures relevant to FDI upgrading and HVA development that link external embeddedness of TNC foreign operations with their embeddedness in the wider TNC network for mutual beneficial outcomes to materialize. These include (i) the role and degree of strategic decision-making autonomy within the subsidiary, to build up a unique position within the TNC by tapping into external networks and locational assets, with associated activity or functional mandates performed for the wider TNC; (ii) embeddedness of the subsidiary within the wider TNC network in terms intra-organizational relationships with other units of the TNC and/or the parent company, which inter alia relates to the centrality of a subsidiary's position within the TNC network, as well as highlighting the "dual embeddedness" of subsidiaries (Meyer et al., 2011), i.e. in host country and within the TNC; (iii) related to this, the degree of TNC differentiation and specialization and extent to which they are developing their subsidiaries into differentiated networks where some subsidiaries are more central then others to overall TNC performance and competitiveness; (iv) the TNC's overall strategic objectives and extent to which subsidiaries can contribute to these and deliver outcomes that boost the competitive advantage of the TNC as a whole and contribute to overall TNC performance.

Thus, among the central factors that contribute to FDI upgrading and associated subsidiary development towards HVAs lie the complex interactions of host country embeddedness and local networks, intra-organizational relationships within the TNC and the granting of strategic autonomy, which in turn are influenced by the overall strategy and strategic objectives of the investing TNC. The following evidence from developed countries may shed important light on these matters and may provide useful pointers for policy in low-income countries.

\section{Evidence and lessons FDI upgrading from a "developed" country context}

These issues were investigated by the authors through a set of large-scale representative micro-level survey-based studies in the United Kingdom, Germany and Scandinavia, which included subsidiaries of major FDI source countries from the developed world, as well as a supplementary census of German parent companies (Gammelgaard et al, 2009, 2012; Hoppe et al 2003; McDonald et al, 2003, 2005; 2011). On the whole, these studies, which were summarized in detail in recent UNCTAD research notes by the authors (Tüselmann and Buzdugan 2013; Tüselmann and Buzdugan 2016), found that the strategic development of TNC subsidiaries, necessary for FDI 
upgrading and subsidiary development towards higher value added activities, is less pronounced than generally assumed. Only a significant minority of TNCs were found to be strategically developing their subsidiaries by granting them higher level mandates and strategic decision-making autonomy; to be deeply embedded into local networks in their host locations and to be performing some form of HVA. Embeddedness in local, regional or national supply chains was found to be particularly low. Furthermore, the majority of subsidiaries in the countries surveyed were shown to be only lightly embedded in their host location as a result of being geared to supply and develop domestic markets, highlighting the continuing importance of the export enhancing nature of FDI among developed countries.

There was little evidence that a large number of subsidiaries have considerably increased value added, deepened linkages to local, regional or national supply chains or experienced a substantial upgrade in their strategic decision making autonomy, which is associated with fostering subsidiary development and specialisation, in recent years. This is despite the case that the majority of foreign-owned subsidiaries are relatively mature, having been in foreign ownership for many years and having had a long period in which to develop host-location linkages.

The insights provided by this research may indicate that a number of host locations, even in highly developed countries, may lack desirable asset bases and capabilities that are attractive for a large number of TNCs to develop and upgrade their FDI. Put differently, the results may indicate that many domestic suppliers are not internationally competitive, despite the increasing importance attached to by TNCs to develop global or EU-wide supply chains; that many locations lack appropriate network infrastructures and/or institutional frameworks. The findings of the study also indicate that the majority of TNCs are not looking for such embeddedness factors for their investments. Indeed, the parent companies surveyed in the studies above highlighted that they attached far less importance to embeddedness factors compared to subsidiary managers. This highlights that even if subsidiaries embed deeply in their host locations, not all of these are candidates for subsidiary upgrading, which may point to an over-investment of a section of subsidiaries into these factors without them increasing HVA and moving into a more central position within the TNC network.

These issue notwithstanding, in a developed country context, the results of the studies above show that although FDI upgrading, deep integration into host locations and subsidiary development are generally uncommon, when these elements are present, they are associated with direct economic benefits for both the host countries and TNCs in terms of increased export intensity, productivity 
level and growth, skilled employment and subsidiary performance (with the latter perhaps being an important contributor to overall TNC competitiveness and performance and thus an important precursor for subsidiary upgrading). In short, the deepening of FDI and subsidiary development towards more HVA has the potential to create win-win situations for both host countries and investors. With regard to the direct employment effects of FDI upgrading, the studies above show that the main effects are not strongly related to employment growth but are instead related to a shift in the skills composition in these subsidiaries towards an increase in skilled jobs and a decrease in unskilled jobs, with associated labour market effects.

The studies also revealed the complex processes involved between subsidiary upgrading and winwin outcomes for investors and host countries - whereby direct and indirect routes exist between increased autonomy, embeddedness and such mutual beneficial outcomes. The deepening of embeddedness in host locations in terms of network relationships was found to be among the main contributors to positive mutual beneficial outcomes, with the granting of strategic decision-making autonomy and strong intra-TNC relationships being primary facilitators in the development of networks in the host location. Put differently, the cultivation of embeddedness in host locations, which is the prime driver of positive subsidiary outcomes, requires the establishment of internal embeddedness and relationships within the TNC to bring the subsidiary into a more central position

within the TNC network. In turn, this may facilitate the granting of mandates and strategic decisionmaking authority to tap into and effectively utilize local networks and local asset bases.

Furthermore, as highlighted by the parent company survey, the results underscore that deepening local embeddedness by subsidiaries, per se, is a necessary but not sufficient requirement for beneficial economic outcomes, if not underpinned by the facilitating role of intra-TNC embeddedness and granting of strategic autonomy that enable the subsidiary to contribute to the overall competitiveness and strategic objectives of the TNC.

\section{Potential economic benefits of integrating "new" industrial policy and FDI upgrading in low and lower-middle income countries}

Whilst such potential benefits have been drawn from the research conducted in the developed countries above, they are nonetheless very much aligned with the overarching findings of a host of recent studies on the impact of FDI in developing countries, which we examine below, particularly with regard to the need for government policies that establish the conditions in order to attract the "right" type of FDI and to engage with TNCs in order to increase HVAs. Furthermore, to underscore the "win-win" nature of such policies, which reconciles the investment objectives of investors with the investment and development needs of developing countries (Hallam, 2009), there 
is some evidence from the agriculture/agribusiness sector in "developing" countries which shows that investors who are well integrated and embedded in the host location yield not only economic benefits for host country but also exhibit better firm performance compared to those that are only lightly embedded (World Bank, 2014; Zhan, Mirza and Speller, 2015).

Thus, a wide ranging and in depth survey of the literature on the impact of FDI on development, performed by the Trade and Competitiveness Global Practice Group at the World Bank, concluded:

The benefits from FDI are not automatic. Indeed, the extent to which countries regulate investment and devise other policies affecting spillovers can have a direct impact on the economic and social effects of FDI. Thus, the importance of governments is to obtain the "right mix" of policies to properly manage different types of FDI. Historically, inadequate design and/or implementation of appropriate policies may, on many occasions, have prevented developing countries not only from attracting, retaining and linking FDI within the domestic economy, but also from maximizing FDI benefits (Echandi et al. 2015:6).

In other words, they argue, "the key point is that for policy makers in many developing countries, the real question is not whether to choose between FDI and domestic investment, but rather how to connect them" (Echandi et al. 2015: 6 emphasis added). In this respect, recent studies such as Farole and Winkler (2014) and Moran (2014) are beginning to acknowledge the necessity of industrial policy and government management of FDI in order to significantly enhance its benefits in developing countries.

With regard to "new" industrial policy, Moran (2014) shows through the analysis of five case studies - Costa Rica, the Czech Republic, Malaysia, Morocco and South Africa - that efforts by these governments to invest in inter alia infrastructure, enhance labour skills and bolster domestic supplier networks were met with increases in the attraction of TNCs which diversified local production and exports, as well as increased backward linkages in the host economy. Moran (2014: 32) terms such interventions "light-form industrial policy", which in essence corresponds to the approach advocated by Justin Lin, discussed above, whereby interventions should arguably be limited to improving market conditions for local industries within a country's endowment structure. Based on their own research, Farole and Winkler also arrive at a very similar policy prescription:

The trick is to fashion a light-handed industrial policy that focuses mostly on overcoming market failures or capturing coordination externalities, including packages of infrastructure expenditures and public-private vocational training initiatives. But in promoting linkages through targeted sector strategies, it is important that those chosen sectors conform to reasonable projections of comparative advantage (Farole and Winkler 2014: 268). 
Yet, Farole and Winkler (2014: 255) also find that "in many developing countries, a large share of the supplies, services, and skills demanded by foreign firms simply does not exist". This suggests, that this "new" form of industrial policy need not be so "macro" and "light touch" -- it incorporate more "micro" level interventions to support the emergence and competitiveness of domestic suppliers, as discussed above. Such "micro" level interventions - such as government programs to support quality improvement, timeliness of delivery and investment in equipment and technology, which Farole and Winkler (2014: 128) show are demanded of domestic suppliers by TNCs in the mining industry in Chile, Ghana and Mozambique - can complement more "light handed", "macro" level interventions involving the improvement to infrastructure, skills development and investment climate issues.

Such a mix of "micro" and "macro" level approaches to "new" industrial policy (what we agree constitutes a "middle path" approach, as discussed earlier) was shown to be successful in a number of recent case studies examined by the Economic Commission for Latin America and the Caribbean (ECLAC) in Central America (Pérez 2014). The study shows for instance, that the application of "new" industrial policy in El Salvador and Guatemala focussed on the promotion of activities in the industrial, the primary commodity and services sectors that had higher rates of productivity, that were more technology and knowledge intensive and involved the participation of small enterprises, with the intention to build local capacity, promote HVAs and allow local firms to move to higher levels of the global value chain (Pérez 2014). Such activities included formulating and applying good biosafety practices in order to prevent outbreaks of diseases, in the case of shrimp cultivation in El Salvador; the creation of new national, regional and local institutions by the government to promote innovation in textile manufacturing amongst local firms, as well as partnerships between academia and trade associations to promote "know how" amongst workers, in the case of garment manufacturing in El Salvador; and the promotion of diversification of agricultural production through incentives, in such areas such as the production of organic produce and oriental vegetables, within the non-traditional export vegetable chain in Guatemala (Pérez, 2014).

These cases highlight that unlike "old" forms of industrial policy, "new" industrial policy need not be oriented towards the industrial sector - they can and should be applied to sectors such as services, agriculture and natural resources. This is particularly important with regard to low-income economies in regions such as sub-Saharan Africa, whereby the agriculture and natural resources sectors are dominant in a majority of the economies and have, therefore, attracted resource seeking inward FDI. In the case of the agriculture and natural resources sectors, industrial policy aimed at 
activities in these sectors - such as training in resource extraction and training in processing - can promote learning, and therefore contribute to the development of local capabilities, as a prerequisite to the emergence of competitive domestic suppliers and FDI upgrading. However, learning can also come from industrial policy focussed on sub-activities linked with resource extraction, such as the construction of buildings, the management of human resources, and the provision of transportation and logistics, which can have spill-over effects towards HVAs across industries and sectors (Greenwald and Stiglitz, 2014). Together, the development of activities associated with human resources and skills, infrastructure and domestic suppliers form a network which have been found, as we have shown above, to be at the core of subsidiary development, and thus HVAs, as they promote embeddedness of existing FDI, whether resource or market seeking.

As outlined above, one other key part of a successful "new" industrial policy is for inward investment to be structured in a manner that is conducive to facilitate upgrading, promoting spillovers and increasing HVAs. With regard to the recent economic development literature on the impact of FDI in in a developing country context, only some clarity has emerged on the influence of this aspect. For instance, Farole and Winkler (2014) demonstrate that joint-ventures, long-term investments (particularly in sector with high rent potential, such as mining) the use of formal contracts, market-seeking FDI (rather than efficiency-seeking and resource-seeking FDI), significantly contributes to spillover effects, though efficiency seeking FDI may bring greater potential spillovers in the long-run if it is linked with producing at higher levels of GVCs. However, control over factors such as whether FDI is market-seeking, efficiency-seeking or resource-seeking is not always an option for developing countries. Therefore, the insights gleaned from the developed country studies discussed above, showing that subsidiaries with sufficient strategic autonomy and embeddedness in local networks are more likely to upgrade FDI activities, may point the way toward future research and policy in the way that developing countries manage inward FDI. Indeed, these studies show that even after controlling for entry mode and for market, resource and efficiency seeking factors, etc., embeddedness in host economies (in particular), subsidiary strategic decision making autonomy and embeddedness in the wider TNC internal networks remain important predicators for FDI upgrading towards HVA and positive outcomes for the TNC and the host economy.

Taken together, the insights above from a "developing" country context, with regard to "new" industrial policy and harnessing the developmental potential of FDI, and from a "developed" country context, outlining the factors which contribute to FDI upgrading, lead to a set of policy considerations for low and lower-middle income countries, which we set out below. 


\section{Conclusion: Considerations for industrial policies for deepening FDI for production upgrading}

As UNCTAD has rightly stated in its recent agenda for the future of investment and development, "meeting the challenge of investment for development, in particular achieving the [UN Sustainable Development Goals], requires among others that investment is reconfigured to better harness the contribution of TNCs for development, especially in light of the contemporary TNC universe and the new balance between the public and private sectors" (UNCTAD, 2014: 1). Yet, it is currently a tall order for low income countries to pursue an "MNC assisted development strategy" (Narula and Dunning, 2010) based on attracting of higher value added FDI and upgrading existing FDI towards more higher value added operations. Apart from the "fundamentals" (conducive institutional and regulatory frameworks, good governance structures, political and economic stability, and so forth), this will require locational asset bases and local network infrastructures that are attractive for TNCs to upgrade their activities; related policies that enhance local capabilities an absorptive capacity conducive for FDI upgrading; as well as policies to correct any market and/or co-ordination failures. Moreover, such policies need to be informed by an understanding of the complex interactions involved in TNC subsidiary upgrading, the internationalisation processes within TNCs and TNC strategies and objectives.

Although such a "high road" approach to economic development and industrial upgrading through FDI upgrading and higher value added FDI appears very demanding for low income countries, it confers, as shown by the studies and the recent literature on FDI in developing countries above, substantial benefits in terms of productivity advances, skills-upgrading and so forth. Furthermore, the trend towards increasing specialisation and fine-slicing of the value activities in TNCs (Buckley, 2014), may provide new opportunities (and risks) for lower income countries for the pursuit of a "high road" FDI approach. Such fine-slicing may lead to greater international diversification of higher value added activities of the TNC, as these entail both specialised and standardised tasks and activities across all functional areas (even within the R\&D function) (Meyer et al., 2011).

In addition, developing countries need not "go it alone" in making the most of FDI through the application of "new" industrial policy and pursuit of the "right" type of FDI. For example, as Moran (2014: 37) rightly argues, "support for emerging market economies to use FDI to upgrade and diversify their production and export base - and to develop reliable and competitive supply chains deep into the local economy - is the new frontier for assistance from the developed country 
and multilateral donor community". Whilst we agree with Moran on this point, we would add that this new frontier for the donor community also includes support for developing local networks (such as clusters of domestic firms, research institutes/universities, supportive government agencies/local authorities) and developing links with effective domestic institutions, which we have shown above to be integral to FDI upgrading. Indeed, the possibilities for donors to assist with the implementation of a "new" industrial policy raises a key issue: Given the potential gains from FDI upgrading, how can limited national resources, overseas development aid (ODA) and international investment of low and lower middle income countries be prioritised, combined, targeted and tailored for a requisite "new" industrial policy to promote productive capacity building, development of locational assets and local networks that are attractive for TNCs for FDI upgrading? Some recent examples in the agricultural sector, for instance, shed light on the possibilities for multi-stakeholder partnerships in this area, which have been championed by the UN as a means of achieving the SDGs (UN 2016): the case of Africado, a Tanzanian avocado and avocado oil producer stands out as an example of FDI in the form of overseas development financing, which has seen the implementation of an out-grower scheme to train and involve 2,400 smallholders in avocado production for export (Bachke and Haug 2014); and the case of the African Cashew Initiative, in which the German TNC, SAP, together with multiple stakeholders such as African states and farmers, regional business associations, international NGOs, international development agencies, has successfully worked to integrate informal parts of the cashew value chain into GVCs through a "virtual cooperative" (Franz et al. 2014).

Policies to make the most of FDI certainly need to be context-specific, considering the diversity of low and lower-middle-income countries in terms of their factor endowments, institutions, geography, labour composition, market size and political power, amongst other characteristics. However, a number of core policy considerations can be applied, given the recent findings that cut across these sets of countries (UNECA 2016; Pérez 2014; Farole and Winkler 2014; Moran 2014). Such policies can be divided into two areas. The first area includes policies to attract and retain the "right" type of FDI, as well as potentially "upgrade" the activities and investments of existing FDI, such as developing the labour force to engage with new activities, supporting the availability and reliability of supplier networks, investing in infrastructure and strengthening the country's legal framework to facilitate entry into long-term contracts between foreign investors and local firms. In this regard, the findings and policy recommendations of Farole and Winkler (2014) are instructive though, we challenge their view to "use industrial policy in a light-handed way that focuses mostly on overcoming market failures or capturing coordination externalities" (2014: 268). As we pointed out above, for instance, their findings show that "in many small developing countries, the reality is 
that no local suppliers exist for a share of the large-value, strategic inputs required by foreign investors" (2014: 255). In these cases, there is scope for adopting an approach to "new" industrial policy that focuses on such "micro" level issues as actively supporting the creation of such supplier networks whilst not losing sight of more "macro" level priorities such as improving the overall legal framework in order to protect property rights. It is doubtful otherwise, given the results of the "developed" country studies that we have discussed above, that TNCs will "take a lead role in planning and implementing supplier development programs" as Farole and Winkler (2014: 272) suggest, without such supplier networks already in place.

The second area of policy considerations involve policies intended to allow countries to better engage with existing and potential foreign investors in order to establish a more thorough understanding of their priorities and constraints, given their complex subsidiary-headquarters relationship structures and drives. In this regard, the findings of Moran (2014: 35) are a useful starting point: "the data reviewed in this paper confirm that there is demonstrable payoff to targeting investors in sectors and to developing expertise about the characteristics and needs of international companies in those sectors. This is a complicated and expensive undertaking, and would-be hosts that want to use FDI to upgrade and diversify the production and export base of their economies need training and counseling". Such findings underscore the point we make here that attracting and retaining the "right" type of FDI does not only rely on countries successfully implementing policies in the first area above, but that such success hinges on establishing productive relationships with foreign investors based on insights into their operations and requirements.

Industrial policy that harnesses the potential of FDI involves a reconfiguration - that is, moving toward an activity based and internationally connected set of strategies that harness extraterritorial economic linkages for FDI deepening and production upgrading, which, especially in the context of GVCs, may also require respective trade policy reforms. Indeed, a country's design and implementation of "new" industrial policy requires careful co-ordination with its investment and trade policies, its investment agreements and other policies within a coherent, integrated, consistent and cohesive set of policies geared towards its overall development objectives, that form part of the broader sustainable development strategy within a framework of a generally favourable investment climate.

Given the insufficiencies of development strategies that have focussed more on liberalisation than on economic transformation, TNC-assisted production upgrading (with proper economic, social and 
environmental safeguards in place) may be a viable route towards sustainable development in low and lower-middle-income countries. 


\section{References}

Andersson U., Björkman I., Forsgren M. (2005) "Managing subsidiary knowledge creation: the effect of control mechanisms on subsidiary local embeddedness", International Business Review, Vol. 14, pp. 521-538.

Bachke, M.E. and Haug, R. (2014) "Food Security in a climate perspective: What role could the private sector play regarding investment in smallholder agriculture in Ethiopia, Malawi, Mozambique, Tanzania and Zambia?", Noragric Report No. 72, Norwegian University of Life Sciences, Aas, Norway.

Bartels, F., Buckley, P. and Mariano, G. (2009) "Multinational enterprises" foreign direct investment location decisions within the Global Factory, UNIDO Working Paper 04/2009, Vienna.

Birkinshaw J, Hood N, and Young S. (2005) "Subsidiary entrepreneurship, internal and external competitive forces, and subsidiary performance", International Business Review, Vol. 14, pp. 227248.

Buckley, P.J. (2014) The Multinational Enterprise and the Emergence of the Global Factory, Palgrave Macmillan, Basingstoke.

Cantwell, J. A. and Mudambi, R. (2011) "Physical attraction and the geography of knowledge sourcing in multinational enterprises”, Global Strategy Journal, Vol. 1, No. 3-4, pp. 206-232.

Chen, G., Geiger, M. and Fu, M. (2015) Manufacturing FDI in Sub-Saharan Africa: Trends, determinants and impact, World Bank, Washington, DC.

Coe, N.M. and Perry, M. (2004) "Promoting linkage to foreign transnationals in a "tiger state": Singapore and Local Industry Upgrading Programme", Environment and Planning C: Government and Policy, Vol. 20, pp. 363-382.

Dunning J. (2009) "Location and the multinational enterprise: John Dunning's thoughts on receiving the Journal of International Business Studies 2008 Decade Award", Journal of International Business Studies, Vol. 40, pp. 20-34.

Echandi, R., Krajcovicova, J. and Qiang, C.Z. (2015) "The impact of investment policy in a changing global economy: a review of the literature", World Bank Policy Research Working Paper (7437).

Farole, T. and Winkler, D. (2014) Making foreign direct investment work for Sub-Saharan Africa: local spillovers and competitiveness in global value chains, World Bank, Washington, DC.

Franz, M., Felix, M. and Trebbin, A. (2014) "Framing smallholder inclusion in global value chains - case studies from India and West Africa", Geographica Helvetica, Vol. 69, pp. 239-247.

Gammelgaard, J., Mcdonald, F., Tüselmann, H., Dörrenbächer, C. and Stephan, A. (2009) "Subsidiary Role and Skilled Labour Effects in Small Developed Countries", Management International Review, Vol. 41, No. 1, pp. 27-42.

Gammelgaard, J., McDonald, F., Tüselmann, H.J., Dörrenbächer, C. and Stephan, A. (2012) “The impact of changes in subsidiary autonomy and network relationships on performance",

International Business Review, Vol. 20, No. 5, pp. 1158-1172. 
Gereffi, G. (2014) "A Global Value Chain Perspective on Industrial Policy and Development in Emerging Markets”, Duke Journal of Comparative and International Law, Vol. 24, pp. 433-548.

Goshal, S. and Bartlett, C.A. (2005) "The multinational corporation as an inter-organizational network", in Goshal, S. and Westney, D.E. (eds) Organizational Theory and Multinational Corporations, Palgrave Macmillan, Basingstoke.

Greenwald, B., and Stiglitz, J.E. (2014) "Learning and Industrial Policy: Implications for Africa". In J.E. Stiglitz, J.Y. Lin, and E. Patel (eds), The Industrial Policy Revolution II: Africa in the 21st Century (pp 25-49). Houndmills, UK and New York: Palgrave Macmillan.

Hallam, D. (2009) "Foreign Direct Investment in Developing Country Agriculture - Issues, Policy Implications and International Response", Global Forum on International Investment, OECD, Paris.

Harrison, A. and Rodriguez-Clare, A. (2009) "Trade, Foreign Investment and Industrial Policies for Developing Countries", National Bureau of Economic Research Working Paper Series, National Bureau of Economic Research, Cambridge MA.

Hausmann, R., Rodrik, D. and Sabel, C.F. (2008) "Reconfiguring Industrial Policy: A Framework with an Application to South Africa", CID Working Paper No. 168, Center for International Development, Harvard University, Cambridge, MA. Available at: http://www.hks.harvard.edu/content/download/69285/1249950/version/1/file/168.pdf

Henderson, J., Dicken, P., Hess, M., Coe, N., and Yeung, H. (2002) "Global production networks and the analysis of economic development", Review of International Political Economy, Vol. 9, No. 3, pp. 436-464.

Heumesser, C. and Schmid, E (2012) "Trends in Foreign Direct Investment in the Agricultural Sector of Developing and Transition Countries: A Review", Universität für Bodenkultur Wien, Vienna.

Holm, U. and Pedersen, T. (2000) The Emergence and Impact of MNC Centres of Excellence - A Subsidiary Perspective, Palgrave Macmillan, Basingstoke.

Hoppe, U., McDonald, F., Tüselmann, H. and Williams, D. (2003) "Quantitative and Qualitative Employment Effects of Foreign Direct Investment on Home and Host Countries", Report to the Anglo-German Foundation for the Study of Industrial Society; Project Number: 1333, London and Manchester.

Kolk, A, Kourula, A. and Pisani, N. (2017) "Multinational enterprises and the Sustainable Development Goals: what do we know and how to proceed?" Transnational Corporations, Vol. 24. No. 3, pp. 9-32.

Lin, J. Y. (2010) “Six Steps for Strategic Government Intervention”, Global Policy, Vol. 1, No. 3, pp 330-31.

Lin, J. Y. (2012a) New Structural Economics: A Framework for Rethinking Development and Policy, World Bank, Washington D.C.

Lin, J. Y. (2012b) "From Flying Geese To Leading Dragons: New Opportunities and Strategies for Structural Transformation in Developing Countries", Global Policy, Vol. 3, No. 4, pp. 397-409. 
Lin, J. Y. and Chang, H. (2009) "DPR Debate: Should Industrial Policy in Developing Countries Conform to Comparative Advantage or Defy it? A Debate Between Justin Lin and Ha-Joon Chang", Development Policy Review, Vol. 27, No. 5, pp. 483-502.

McDonald, F., Tüselmann, H., Heise, A. and Williams, D. (2003) "Employment in host regions and foreign direct investment", Environment and Planning C: Government and Policy, Vol. 21, No. 5, pp. 687-701.

McDonald, F., Tüselmann, H., Dimitratos, P. and Voronkova, S. (2005) "The strategic development of foreign owned subsidiaries and employment in host locations in the UK", Environment and Planning C: Government and Policy, Vol. 23, No. 6, pp. 867-82.

McDonald, F., Tüselmann, H., Voronkova, S. and Golesorkhi, S. (2011) "The strategic development of subsidiaries in regional trade blocs", Multinational Business Review, Vol. 19, No. 3, pp. 256-71.

McDonald, F., Gammelgaard, J. Tüselmann, H., Stephan, A. and Dörrenbächer, C. (2015) "Cities and the autonomy and network relationships of foreign subsidiaries: the case of Greater Copenhagen", Academy of International Business UK \& Ireland Chapter Conference Proceedings, Manchester.

Moran, T., (2014) "Foreign investment and supply chains in emerging markets: Recurring problems and demonstrated solutions", Working Paper 2014-12, Peterson Institute for International Economics, Washington, DC.

Meyer, K.E., Mudambi, R. and Narula, R. (2011) "Multinational enterprises and local contexts: the opportunities and challenges of multiple-embeddedness", Journal of Management Studies, Vol. 48, No. 2, pp. 235-252.

Narula, R. and Dunning, J. H. (2010) "Multinational enterprises, development and globalisation: some clarifications and a research agenda", Oxford Development Studies, Vol. 38, No. 3, pp. 263287.

Peng, M.W., Wang, D.Y.L., Jiang, Y. (2008) "An institution-based view of international business strategy: a focus on emerging economies", Journal of International Business Studies, Vol. 39, No. 5, pp. 920-936.

Pérez, R.P. (2014) Strengthening value chains as an industrial policy instrument: Methodology and experience of ECLAC in Central America, Economic Commission for Latin America and the Caribbean (ECLAC), United Nations, Santiago, Chile.

Porter, M. and Sövell, O. (1998) "The role of geography in the process of innovation and sustainable competitive advantage of firms", in Hagstrom and Sövell, O. (eds), The Dynamic Firm: The Role of Technology, Strategy and Regions, Oxford University Press, Oxford.

Rodrik, D. (2004) "Industrial Policy for the Twenty-First Century", Paper prepared for UNIDO. Available at: https://research.hks.harvard.edu/publications/getFile.aspx?Id=146.

Rugman, A, Verbeke, A. and Yuan, W. (2011) "Re-conceptualizing Bartlett and Goshal's classification of national subsidiary roles in the multinational enterprise", Journal of Management Studies, Vo., 48, No. 2, pp. 253-277. 
Schaffnit-Chatterjee, C. (2014) "Agricultural value chains in Sub-Saharan Africa: From a development challenge to a business opportunity”, Deutsche Bank Research: Current Issues in Emerging Markets, Frankfurt.

Stiglitz, J., Lin, J.Y., Monga, C., and Patel, E. (2013) "Industrial Policy in the African Context", Policy Research Working Paper 6633, World Bank, Washington, DC.

Tüselmann, H. and Buzdugan, S. (2013) "Beyond the attraction of foreign direct investment in regional integration: Micro-level evidence and implications of promoting 'deep' levels of investment for growth and development", UNCTAD Expert Meeting on Regional Integration and Foreign Direct Investment, 28-30 January 2013, UNCTAD, Geneva.

Tüselmann, H. and Buzdugan, S. (2016) "Making the most of FDI for industrial upgrading and development: Harnessing IIA policy-space through evidence based lessons for "new" industrial policy", UNCTAD Expert Meeting on Reforming International Investment Agreements, 16 March 2016, UNCTAD, Geneva, http://unctad-worldinvestmentforum.org/?page_id=9740\&preview=true

Haque, I.u. (2007) “Rethinking Industrial Policy”, UNCTAD Discussion Paper No. 183, United Nations Conference on Trade and Development (UNCTAD), Geneva. Available at: http://unctad.org/en/docs/osgdp20072_en.pdf

UN DESA (2016) "Supporting the Sustainable Development Goals Through Multi-Stake-Holder Partnerships - Ensuring That No One Is Left Behind”, Partnerships for Sustainable Development Goals Special Report 2016, United Nations, Geneva, available at: https://sustainabledevelopment.un.org/sdinaction/2016report

UNCTAD (2012) World Investment Report 2012, United Nations, Geneva.

UNCTAD (2013) Global Value Chains and Development: Investment and Value Added Trade in the Global Economy, United Nations, Geneva.

UNCTAD (2014a) World Investment Report 2014, United Nations, Geneva.

UNCTAD (2014b) The Global Academic Policy Research Network on Investment for Development, United Nations, Geneva.

Wade, R.H. (2012) "Return of industrial policy?", International Review of Applied Economics, Vol. 26, No. 2, pp. 223-239.

Weiss, J. (2011) "Industrial Policy in the Twenty-First Century: Challenges for the Future", Working Paper No. 2011/55, UNU-WIDER, Helsinki, Finland.

World Bank (2014) "The practice of responsible investment principles in larger-scale agricultural investments: Implications for corporate performance and impact on local communities", World Bank Report, Number 86175-GLB, Washington DC.

Zhan, J., Mirza, H. and Speller, W. (2015) "The impact of large scale agricultural investments on communities in South East Asia: A first assessment", International Development Policy, Vol. 6, No. 1. 